\title{
Place of Family and Family Values in Worldbasic Religions (Christianity, Islam, Buddhism)
}

\author{
E.V. Bobyreva \\ Theory of English department \\ Volgograd State Socio-Pedagogical University \\ Volgograd, Russia new life@mail.ru
}

\author{
O. A. Dmitrieva \\ Department of Russian as a Foreign Language \\ of the Faculty for the Training of Foreign Citizens \\ Volgograd State Socio-Pedagogical University \\ Volgograd, Russia dmoa@yandex.ru
}

\begin{abstract}
Questions of globalization process which influence various aspects of human life are considered in the article. Destruction of cultures and cultural values act as a result of this process. Destruction of family values is an important problem in the modern world. Religion presents a restraining mechanism of such destruction. Islam turned out to be the strongest in the ability to confront new tendencies which allowed to preserve and strengthen the family institute in Muslim countries. Christianity couldn't totally avoid the process of destruction of family values (in spite of some recent attempts to improve traditional institute of the family). Buddhism does not pay particular attention to the institute of the family and corrects ethical and moral behavior of a person through other religious mechanisms.
\end{abstract}

Keywords-globalization, values, culture, Christianity, Buddhism, Islam, social institute.

\section{INTRODUCTION}

Globalization process (process of the global economic, political, cultural and religious integration and unification) representing the main direction of mankind's development exerts huge impact on various aspects of people's life.First of all, various social processes and various aspects of social life are exposed to influence. However, private life of representatives of the society doesn't stand aside. In this article influence of globalization on development (or rather transformation) of the main family values will be considered [8].

\section{DISCUSSION}

1. Pluses and minuses of globalization in respect of family values:

On the one hand,globalization presents a progressive process; though, on the other hand, this process anticipates certain loss of national cultural values by the definite nation (people). As for religion, the pluralism and eclecticism of religious views extends not only at the level of various societies, but also at the level of individual consciousness of believers [4]. In the context of globalization,religion is based on eclectic world outlook, that is, it combines elements which are not connected either logically or genetically, elements which have been drawn from different traditional religions, quasi- scientific and vice versa primitive folklore ideas, rethought images of mass culture [4]. It all leads to the distortion of the basics of faith which presents a special relationship of a personwiththe surrounding world, with other people and with God; it also leads to the distortion of both person's and society's valuable priorities - situation which in its turn can sooner or later lead to the distortion of the identity and cohesion ofsociety and undoubtedly of the whole nation [10].

\section{Destruction of family values}

Destruction of basic family values on a global scale presents a fundamental problem about which still John Chrysostom has told so: "Family breakdown upsets the whole universe" and, conversely, "if marital relations are normal, then the children are brought up well, and the servants are decent, and the neighbors, and friends and relatives rejoice, and all are pleased with the consent of the spouses".

Today we are the witnesses of how actively mass media imposes values alien to the Christian religious world [6]. It tries to simulate understanding of a family and love for the neighbor alien to the Christians. A lot of young people are disoriented so much and they can't understand what "Christian family" means. There are a lot of ridiculous stamps and examples of the modern model of the relations of a young boy and a young girl including those which are imposed by mass-media (Programme "Home 2" on TNT channel).

In the Russian society there exists an alien concept of "civil marriage" involving strengthening of anti-family installations in the society.Young people who get married can't understand the essence of Christian morality and prefer to get divorced as soon as there is the first conflict (it is confirmed by statistics that half of the marriages are ended up by divorce), though conflicts are just natural in the process of building a family.

3. Modern education and attempts to preserve family values So spiritual and moral development of the Russian citizens as well as formation of moral values present a primary task of modern educational system and represents a social order of education [5]. So family and family values are the most important things. 
4. Family values in Christianity

Traditional Russian family values were formed due to the acceptance of Orthodoxy by the Great prince Vladimir. Christian understanding of marriage and family had been fundamental for Russia almost during one thousand years. So what Christian family values are? The following Russian traditional family values can be highlighted: monogamy, chastity, conjugal fidelity, family centrism (prestige of the family), social approval of marriage (through official registration, parental approval and wedding), connection of generations, hierarchy, inviolability of marriage, large families.

Relying on Biblicaland theological sources we can confidently say that Christian morals stated in Bibleprecepts present spiritual basis for the creation and existence of a family. Christian morality defines ideas and concepts about moral and immoral behavior in the family, suggests moral norms for the family relations, emphasizes attention to Christian love which is the basis of a family in Orthodoxy [7]. Opportunity to study the basis of Christian faith which is offered by Sunday schools helps to restore and transmit Christian family values. Itwill also help to strengthen national security of Russia and will allow it to remain one of the leading world powers [2].

\section{Family values in Islam}

As for Islam it demonstrates a special attitude towards family. Family relations and marriage are confessed to be an indisputable value: "The best among you is the person who is the best towards his family". In Islam family creates an environment in which moral and spiritual values are transferred from generation to generation [3]. Muslims consider a family to be an institution prescribed by the Supreme.

Islam is the only religion which has accurately registered requirements for family and marriage. Family and relations between a man and a woman are considered to be a mercy of the Supreme: "And among His Signs is this, that He created for you wives from among yourselves, that you may find repose in them, and He has put between you affection and mercy. Verily, in that are indeed signs for a people who reflect" (Quaran, Surah 30: 21).Islam teaches that the Supreme created everybody in complementary pairs, so men and women have equal spiritual value.

Quaran contains the definite rules (prescriptions and prohibitions) which regulate the process of marriage: a). ban on secret datings (one to one) before engagement and marriage: "And there is no sin on you if you make a hint of betrothal or conceal it in yourself, Allah knows that you will remember them, but do not make a promise of contract with them in secret except that you speak an honorable saying according to the Islamic law. And do not consummate the marriage until the term prescribed is fulfilled. And know that Allah knows what is in your minds, so fear Him. And know that Allah is Oft-Forgiving, Most Forbearing. There is no sin on you" (Quaran, Surah 2: 235);b). obligatory existence ofa marriage contract: "And how could you take it (back) while you have gone in unto each other, and they have taken from you a firm and strong covenant?"'(Quaran, Surah 4: 21); c). payment of the bridewealth provided by the contract (adzhr): "And whoever of you have not the means wherewith to wed free, believing women, they may wed believing girls from among those (slaves) whom your right hands possess, and Allah has full knowledge about your Faith; you are one from another. Wed them with the permission of their own folk (guardians, Auliya' or masters) and give them their Mahr according to what is reasonable; they (the above said captive and slave-girls) should be chaste, not committing illegal sex, nor taking boy-friends...." (Quaran, Surah 4: 25).

Quaran also has accurate instructions whom a person mustn't marry: a). it is forbidden to marry a person who doesn't share your religious views (though besides women of their religion Muslims can marry women who share the faith outlined in the scriptures which were previous to Quaran: Torah, Psalter, Gospel); b). it is forbidden to marry women your fathers were married to; c). it is forbidden to marry close relatives (mother, daughters, sisters, aunts, brother's or sister's daughters, etc.). Quaran forbids a man to have two or more wives unless he treats them equally and can support worthily: "And if you fear that you shall not be able to deal justly with the orphan-girls then marry (other) women of your choice, two or three, or four; but if you fear that you shall not be able to deal justly (with them), then only one or (the slaves) that your right hands possess. That is nearer to prevent you from doing injustice. And give to the women (whom you marry) their Mahr (obligatory bridal-money given by the husband to his wife at the time of marriage) with a good heart..." (Quaran, Surah 4: 3-4).

A person in Islam is estimated on that what he thinks of his family: "Among those who share the faith, the strongest faith has a person who is the most well-behaved and the kindest to his family". And even a person's power of faith is estimated on that what he thinks of his family. Family presents "a castle" which can protect a person and even prolong his life: "If a person spends something on his family, hoping to draw closer to Allah, it will be counted as a charity for him ... the best Dinar a person can spend is the Dinar that he has spent on his children...".

Parents in Islam are honored practically equally with the Allah Almighty and so gratitude to parents is connected with gratitude to the Almighty [9]. Quaran pays particular attention to taking care of parents in old age: "A shame on the one who will leave parents in old age. He won't enter paradise", or: "Return to them and force them to laugh the same as you have forced them to cry". Both disrespect for parents and polytheism are considered the gravest sins in Islam.

Quaran also prescribes a particular attitude to children. A child is considered to be a mercy of Allah and it is the duty of parents to give him propereducation: "Wealth and children are the adornment of the life of this world. But the good righteous deeds, 1 that last, are better with your Lord for rewards and better in respect of hope" (Quaran, Surah 
18: 46). Besides, the child is alsoa responsibility and every person will be asked for taking a proper care of him: "Each of you is a shepherd and each of you is responsible for his flock: the ruler is a shepherd, and the man is a shepherd to his family, and the woman is a shepherd looking after his husband's house and his children. So each of you is a shepherd and each of you is responsible for his flock".

Before the adoption of Islam, it was habitual for Arabs to bury their young daughters alive because of the fear of poverty or shame. Quaran forbade to kill children [18]: "And kill not your children for fear of poverty. We shall provide for them as well as for you. Surely, the killing of them is a great sin"(Quaran, Surah 17: 31).

But the family in Islam is not only parents and children. Family is all numerous relatives. Islam prescribes not only to maintain good relationships with relatives but also to take care of them [1]. It is necessary not only to keep in touch with relatives but to participate sincerely in their life:"He who causes to their related nicknames, just a courtesy call does not fulfill to the end their obligations regarding compliance with the inviolability of family ties. And those who can turn a blind eye to the transgressions of their relatives, forgive them, and visit them in order to strengthen their bonds of kinship will fulfill their obligations in full" (Al-Bukhari).

\section{Family values in Buddhism}

Unlike Christianity and Islam, Buddhism can be referred to the category of "ethical religions" because traditions of Buddhism generated provisions on morals and due behavior. At the same time ethics of Buddhism can't be understood apart from the main goal of Buddhism- "final liberation from attachment to this world".

All actions of a person are lined up on an idiosyncratic scale of "virtues" and "sins" according to the principle of conformity or discrepancy with the "Way of liberation" described in the doctrine of the Buddhism. The main root sins which tire a person to the endless wheel of births and deaths (sansara) are greed (lobha), hatred (dosa) and delusion (moha); all other forms of unrighteous behavior can be reduced to these three sins.

Five main commandments of Buddhism in the modern world are the following: 1. to avoid killing of living creatures; 2. to avoid taking what is not given to you (sometimes it is identified with the prohibition of theft); 3 . to avoid sensual excesses (improper sexual behavior, adultery); 4. to avoid taking substances which intoxicate a person.

Unfortunately,Buddhism does not focus on family values (marriageritual practically does not exist in this religion).

Good deeds which create "positive karma" are reduced to the implementation of five rules and first of all to the manifestation of the qualities which correspond to the ideal of liberation: generosity, avoidance of excesses (though wealth is not condemn directly), overcoming of selfishness, compassion. The main ethical ideal of Bhuddism is compassion (karuna).

Though, norms and requirements which regulate actions and attitude of a person towards himself, focus on compliance to the highest norm and strict adherence to spiritual norms and rules in order to reach "future right rebirth" from our point of view prevents a person from breaking certain norms - and it is true about relations of a man and a woman. In general it is possible to consider Bhuddismthe religion which does not attach significance to preservation of family values as Islam does.

\section{CONCLUSION}

To conclude, we'll point out that without any doubt globalization process has affected all aspects of modern life and all institutesof modern society. The institute of a family doesn't stand aside and it also has undergone the destruction process. Religion presents a particular restraining mechanism of such destruction. Islam and Muslim culture turned out to be the strongest in the ability to confront new tendencies which in its turn allowed to preserve and strengthen the family institute. Christianity though tries to confront process of destruction of the traditional family and to preserve historical cultural values - still can't avoid the process of destruction of the family values. Though particular improvements have been outlined during the recent decades and traditional institute of marriage has started to be restored. Buddhism, owing to its traditions and purposes (aspiration to spiritual improvement of a particular person) does not pay particular attention to the family institute and corrects normative, ethical and moral behavior of a person through other mechanisms.

\section{REFERENCES}

[1] L.I. Almazova, Religious studies and teaching knowledge about religion in modern Tatarstan. Case of Islam. State, religion, church in Russia and abroad, 2017, vol. 4, pp. 139-161.

[2] N.A.Belyakova, M.Dobson, Women in evangelical communities in the USSR of after-war period. - 1940s-1980s. Research and sources. Moscow, "Indrik", 2015, $512 \mathrm{P}$.

[3] E.V.Bobyreva,O.A.Dmitrieva, M.R.Zheltukhina, M.V. Busygina Principle "Understandingfrom Perspective of Linguistic Investigations. Proceedings of the 7 th international scientific and practical conference " Current issues of linguistics and didactics: The interdisciplinary approach in humanities" (CILDIAH 2017): Advances in Social Science Education and Humanities Research, 2017, T. 97, pp. 52-56.

[4] T. Jensen Religious education in state schools: the most important tendencies (primarily on the example of Scandinavia). State, religion, church in Russia and abroad, 2017, vol. 4, pp. 46-71.

[5] A.A.Ozhiganova, Teaching religion at school: search of neutrality and "cultural wars". Introductory article. Stte, religion, church in Russia and abroad, 2017, vol. 4,pp. 7-29.

[6] T.V. Pronina, "Basics of Orthodox culture" at schools in Tambov region: success and problems. State, religion, church in Russia and abroad, 2017, vol. 4, pp. 119-138.

[7] O.Rua, Islam in the West or the western Islam? Break of the connection between religion and culture. State, religion and church in Russia and abroad, 2017, vol. 3, pp. 77-84. 
[8] A.V.Sitnikov, Religious tradition in modern society: experience of theoretical analysis. State, religion, church in Russia and abroad,2017, vol. 3, pp. 77-84.

[9] L.I. Starodubrovskaya,E.A.Varshaver, Who and why approves violence in Dagestan? Comparative analysis of value profiles of Islam religious groups in Dagestan. State, religion, church in Russia and abroad, 2017, vol. 3, pp. 202-233.

[10] M.M. Shakhnovich, Religion at school: modern European landscape. State, religion, church in Russia and abroad, 2017, vol. 4, pp. 30-45. 